\title{
Phytochemical Study and Comparative Antioxidant Activity of Extracts from Aerial Parts of Chenopodium ambrosioides Linn. (Chenopodiaceae)
}

\author{
Gneiny Whad Tchani1 ${ }^{*}$, Kossi Sitsopé Agbeme1, Kokou Agbékonyi Agbodan², \\ Gnon Baba1, Kafui Kpegba1
}

${ }^{1}$ Laboratoire de Chimie Organique et des Substances Naturelles (Lab COSNat), Faculté des Sciences, Université de Lomé, Lomé, Togo ${ }^{2}$ Laboratoire de Génie des Procédés et Ressources Naturelles (LAGEPREN), Département de Chimie, Université de Lomé, Lomé, Togo Email: ^gneinytchani@gmail.com

How to cite this paper: Tchani, G.W., Agbeme, K.S., Agbodan, K.A., Baba, G. and Kpegba, K. (2021) Phytochemical Study and Comparative Antioxidant Activity of Extracts from Aerial Parts of Chenopodium ambrosioides Linn. (Chenopodiaceae). Advances in Biological Chemistry, 11, 220-233. https://doi.org/10.4236/abc.2021.115015

Received: August 25, 2021

Accepted: October 23, 2021

Published: October 26, 2021

Copyright $\odot 2021$ by author(s) and Scientific Research Publishing Inc. This work is licensed under the Creative Commons Attribution International License (CC BY 4.0).

http://creativecommons.org/licenses/by/4.0/

(c) (i) Open Access

\begin{abstract}
The use of Chenopodium ambrosioides in some communities in Togo reveals its importance and its medicinal properties. The plant is often infused for medicinal drinks before use. Thus, through a comparative study, this work focused on the identification of the different phytochemical groups and then on the anti-radical capacities of ethanolic and aqueous extracts of aerial parts (leaves and seeds) of Chenopodium ambrosioides obtained by maceration and infusion. The phytochemical tests, carried out on the various extracts, showed that they contained certain biomolecules such as flavonoids and tannins. Likewise, the presence of terpenoids and terpenes has been detected. However, it is only in aqueous extracts that the alkaloids have been revealed. The determination of the polyphenol content of the extracts revealed that the aqueous infusion contains $25.699 \mathrm{mgGAE} / \mathrm{g} \mathrm{DE}$, followed by the aqueous maceration: $24.873 \mathrm{mgGAE} / \mathrm{g} \mathrm{DE}$, after the ethanolic infusion: $21.009 \mathrm{mg}$ GAE/g DE and of the ethanolic maceration: $20.625 \mathrm{mg} \mathrm{GAE} / \mathrm{g} \mathrm{DE}$. The results of the determination of the anti-radical capacity by the DPPH method after calculation of the $\mathrm{IC}_{50}$, revealed that the infusion gives respectively in aqueous and ethanolic medium: $25.541 \mu \mathrm{g} / \mathrm{ml}$ and $48.269 \mu \mathrm{g} / \mathrm{ml}$ while the maceration leads to $29.187 \mu \mathrm{g} / \mathrm{ml} 50.999 \mu \mathrm{g} / \mathrm{ml}$ respectively. This study showed that each extract reacted with DPPH and the aqueous infusion was the most reactive.
\end{abstract}

\section{Keywords}

Chenopodium ambrosioides, Anti-Radical, Polyphenol, DPPH 


\section{Introduction}

Plants have always been a part of human daily life as we use them for food, for healing, and sometimes use them in our religious rites. Playing very important roles in everyday life, some plants traditionally used to have medicinal properties with great potential for therapeutic applications in the treatment of certain diseases; Africans use medicinal plants from their pharmacopoeia to treat many diseases. These plants contain natural bioactive compounds. Polyphenols, vitamins and carotenoids, known to be antioxidant molecules, are found there [1]. Humans have used herbal remedies throughout their lives and long before, good records have been kept of the herb. World Health Organization has reported that a significant portion of the world's population (75\%) use traditional medicine and pharmacopoeia to cope with health problems [2]. In Africa, the therapeutic power of plants was known empirically by our ancestors and parents [3]. More precisely in Togo, the aerial parts (leaves and seeds) of Chenopodium ambrosioides are used for making herbal teas to treat several pathologies: inflammation, malaria, abdominal pain, digestive parasitosis. The plant is commonly used in traditional medicine in Togo in the treatment of abscesses and infected wounds [4].

In traditional medicine, Chenopodium ambrosioides is used in the care of the circulatory system as a poultice on the forehead and temples as a febrifuge, in infusion, indicated in the treatment of fever, intestines and typhoid [5]. It is also used in herbal tea in Mexico to produce milk in women and to improve blood flow [6]. Its most common traditional form used in Brazil is that the leaves are mixed with milk [7]. Parts of the plant, in this case, the aerial part, are used in the treatment of malaria and diabetes [7]. The use of Chenopodium ambrosioides gives it antioxidant, anti-tumor, anthelmintic, antimalarial, anti-inflammatory, insecticidal, anti-rheumatic, analgesic, sedative and antipyretic properties [6] [8] [9]. An infusion of the plant, dry or fresh, allows good digestion. Some people use this decoction as a stimulant, laxative and against diarrhea. The leaves are often added to the soup to have a good taste. Crushed, they are applied to treat wounds and abscesses. Headaches are relieved by inhaling the aromatic scent of the plant [10] [11].

Medicated drinks are often prepared by aqueous infusion. Unfortunately, the chemical composition and the conditions under which these herbal teas are prepared are not known. However, some active constituents can be denatured by heat. From the above, our work will focus on the aqueous and ethanolic extracts of the aerial parts (leaves and seeds) of Chenopodium ambrosioides growing in Togo in order to know more about their chemical constituents by detecting of the different groups of secondary metabolites based on two extraction methods (maceration and infusion) then determine their anti-radical capacities.

\section{Materials and Methods}

\subsection{Devices}

The instruments we used for this work are: a precision balance, a UV-visible 
spectrophotometer UV-5100B Spectrophotometer a vortex, a centrifuge (SPN-400), a rotary evaporator (Rotavapor), micropipettes, and all kinds of glassware.

\subsection{Products}

\subsubsection{Biomass Harvest}

The plant material for this work consists of the aerial parts (leaves and seeds) of Chenopodium ambrosioides collected at Tsévié-Dalavé (about $50 \mathrm{Km}$ north of Lomé) on October 31, 2019 at the following coordinates: North latitude $6^{\circ} 23^{\prime} 0.042^{\prime \prime}$ and longitude East $1^{\circ} 14^{\prime} 7.692^{\prime \prime}$ during the fruiting period. The harvested plants were authenticated at the Botanical and Plant Ecology Laboratory of University of Lomé (Togo). The leaves and seeds harvested were washed with water and then dried in the dark for a month in order to lower the water content, avoid contamination and keep the active ingredients at room temperature laboratory which is $20^{\circ} \mathrm{C}$. They are then ground into a powder using a grinder and stored away from air and moisture.

\subsubsection{Chemical Reagents}

The reagents used are: DPPH (1,1-diphenyl-2-picryl-hydrazyl), quercetin, iron III trichloride $\left(\mathrm{FeCl}_{3}\right)$ come from the supplier Carlo Erba. Sodium carbonate $\left(\mathrm{Na}_{2} \mathrm{CO}_{3}\right)$ and gallic acid are purchased from Sigma Aldrich. Other chemicals such as chloroform, soda, hydrochloric acid, sulfuric acid have been used. Ethanol, methanol and distilled water served as solvents. All the reagents and solvents were purified according to the methods described in the work published in the scientific literature.

\subsubsection{Study Methods}

\section{Obtaining the ground material}

The aerial parts of Chenopodium ambrosioides (leaves and seeds) collected are washed and dried in the open air and protected from light for a month in order to lower the water content and avoid contamination, and to keep the active ingredients at ambient temperature $\left(20^{\circ} \mathrm{C}\right)$. They are then ground into a powder and stored away from air and moisture.

\section{Preparation of extracts}

The aqueous and ethanolic extracts are prepared based on two extraction methods.

\section{Maceration}

Maceration consists of keeping the drug in contact with a solvent at room temperature for a period of 30 minutes to 48 hours. In the case of herbal teas the solvent is water. This method allows gentle extraction of the active ingredients, especially when they are thermolabile.

The aqueous extraction was carried out by introducing $8 \mathrm{~g}$ of vegetable powder in $80 \mathrm{~mL}$ of distilled water, the mixture is stirred and left to macerate for 24 hours then filtered.

The same steps were followed for the ethanolic extract (95\% ethanol). 


\section{Infusion}

It is prepared by pouring the boiling solvent over the parts of fresh or dried plants and soaking them well to extract their active ingredients, leaving the mixture to stand a few minutes at laboratory temperature (no more than $15 \mathrm{mi}$ nutes).

For the aqueous extract, $8 \mathrm{~g}$ of vegetable powder is introduced into $80 \mathrm{~mL}$ of boiling distilled water and left to infuse for 15 minutes.

The same steps were followed in boiling ethanol (95\% ethanol).

The filtrates obtained are used for the phytochemical and anti-radical studies.

\subsubsection{Phytochemical Test}

Phytochemical screening makes it possible to highlight the presence or absence of groups of chemical families in a plant material. It is based on precipitation and coloring reactions. The method applied is that adopted by Haddouchi et al. [12]; EL-Haoud et al. [13] and Halla et al. [14] modified and adapted to the conditions of the Laboratory of Organic Chemistry and Natural Substances of the University of Lomé.

\section{Detection of flavonoids}

To $0.5 \times 10^{-3}$ liter of each extract, 10 drops of concentrated $\mathrm{HCl}$ and a few $\mathrm{mg}$ of magnesium turnip are added. After 3 minutes of incubation at room temperature, a pink-red or yellow color indicates the presence of flavonoids.

\section{Detection of tannins}

To one milliliter of each extract, add 8 drops of a dilute $1 \% \mathrm{FeCl}_{3}$ solution. At room temperature, the mixture is incubated for a few minutes. In the presence of catechic tannins the coloring is greenish while in the presence of Gallic tannins it is blackish blue.

\section{Detection of alkaloids}

To one $\mathrm{ml}$ of each extract are added $2 \mathrm{ml}$ of $1 \% \mathrm{HCl}$. It is heated in a water bath $\left(60^{\circ} \mathrm{C}\right)$ and then the extract is divided into two equal volumes. One volume is treated with Mayer's reagent-(potassium mercuric + iodide solution) and the other with Wagner's reagent-(solution of iodine in potassium iodide). A yellowish-white precipitate by Mayer's reagent is formed if alkaloids are present in the extract. An orange-red to brown staining by Wagner's reagent leads to the same conclusion.

\section{Detection of saponins}

In a test tube, place $2 \mathrm{ml}$ of each extract and make up with distilled water to obtain $5 \mathrm{ml}$ of solution. The tubes are shaken lengthwise for 15 seconds. Leave to stand for 20 minutes. If the height of the foam is more than $1 \mathrm{~cm}$, the test is positive.

\section{Detection of terpenoids}

To $1 \mathrm{ml}$ of each extract are added, successively, $0.5 \mathrm{ml}$ of chloroform and 0.7 $\mathrm{ml}$ of concentrated $\mathrm{H}_{2} \mathrm{SO}_{4}$. Steroidal heterosides are characterized by a green-blue color and the presence of terpene heterosides gives a green-purple.

\section{Detection of terpenes}


The sample $(1 \mathrm{~mL})$ was placed in a test tube with $1 \mathrm{~mL}$ of concentrated sulfuric acid and heated for two minutes. The appearance of a grayish color of the supernatant indicates the presence of terpenes.

\section{Reducing compounds}

Their detection involves placing $2 \mathrm{~mL}$ of the aqueous extract in a test tube, then $2 \mathrm{~mL}$ of Fehling's liquor $(\mathrm{A}+\mathrm{B})$ is added. Then, the whole is brought to a boiling water bath for 8 minutes. Reducing compounds are detected by obtaining a brick red precipitate.

\section{Cardiac glycosides}

Two (2) $\mathrm{mL}$ of chloroform are poured into $1 \mathrm{~mL}$ of the extract, the appearance of a reddish-brown color after the addition of $\mathrm{H}_{2} \mathrm{SO}_{4}$ indicates the presence of cardiac glycosides.

\section{Free anthracene derivatives}

To $1 \mathrm{ml}$ of the extract dissolved in chloroform ( $1 \mathrm{~g}$ of powder in $10 \mathrm{ml}$ ), dilute $\mathrm{NH}_{4} \mathrm{OH}(1 \mathrm{ml})$ is added. Free anthracene derivatives are detected by a more or less red color after shaking.

\section{Detection of quinines}

In a test tube containing $1 \mathrm{ml}$ of $1 \%$ sodium hydroxide $(\mathrm{NaOH}), 1 \mathrm{ml}$ of the sample is introduced. Everything is well mixed. The presence of quinines is characterized by a blue, green or red coloration.

\subsubsection{Preparation of Dry Extracts}

A mass of $20 \mathrm{~g}$ of powder was macerated for 24 hours and infused in $200 \mathrm{~mL}$ of distilled water and $95^{\circ}$ ethanol. The resulting mixture is filtered through cotton and then through filter paper. The extracts are evaporated at a temperature of $45^{\circ} \mathrm{C}$.

The yields of dry extracts are determined according to the following formula:

$$
\text { Efficiency }(\%)=[\mathrm{P} 1-\mathrm{P} 2 / \mathrm{P} 3] \times 100
$$

P1: weight of the flask after evaporation; P2: weight of the empty flask; P3: product mass.

\subsubsection{Determination of Polyphenols}

The method to be adopted is that used by Ali-Rachedi et al. [15] where a volume of $200 \mu \mathrm{L}$ of each extract was added, with a mixture of $1 \mathrm{~mL}$ of Folin-Ciocalteu reagent diluted 10 times, and $800 \mu \mathrm{L}$ of a solution kept for 30 minutes. The absorbance is read at $765 \mathrm{~nm}$.

\subsubsection{Study of the Anti-Radical Activity of the Different Extracts}

DPPH (2,2-diphenyl-1-picrylhydrasyl) is a free radical that has an odd electron on one of these nitrogen atoms and is the basis of most antioxidant tests. The violet-colored DPPH radical, brought into contact with an extract containing antioxidant molecules, changes color and becomes yellow. This color change is due to the reduced form which no longer absorbs at this wavelength $517 \mathrm{~nm}$ (Scheme $1)$. 


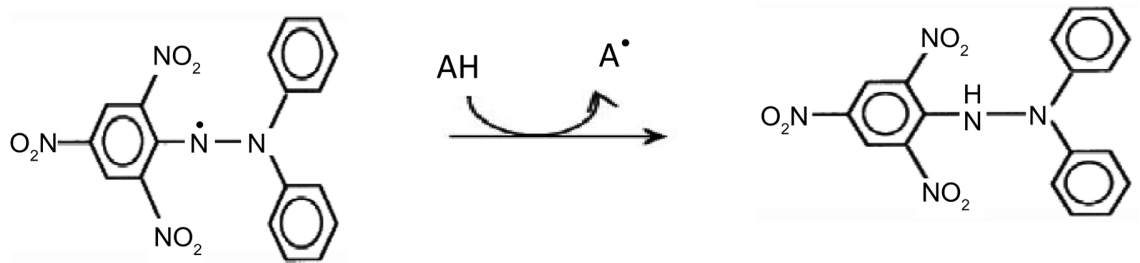

Scheme 1. Reduction of the DPPH radical by an HA molecule (antioxidant) (Haddouchi et al. [12]).

The method described by Dieng et al. [5] to determine the anti-radical activity allowed us to test our different extracts.

The DPPH solution was prepared in ethanol with a concentration of $100 \mu$ $\mathrm{mol} \cdot \mathrm{L}^{-1}$. Each extract is diluted according to concentrations of $(1.8 ; 2 ; 2.2$; $2.5 ; 2.8 ; 3.3 ; 4 ; 5 ; 6 ; 7 ; 10) \mathrm{mg} / \mathrm{mL}$ and the reference (quercetin) according to the following concentrations: $(1.29 ; 1.38 ; 1.5 ; 1.8 ; 2 ; 3) \mu \mathrm{g} / \mathrm{mL}$. Then, to $150 \mu \mathrm{L}$ of extract and the reference are added $3 \mathrm{~mL}$ of the DPPH solution; then the absorbances were measured at $517 \mathrm{~nm}$ after incubation for 30 minutes in the dark. Three tests were carried out for each concentration of product tested.

\subsubsection{Data Processing}

In order to determine the means and the correlation coefficients, an analysis of the results is carried out using Microsoft Office Excel 2010 software. The graphs and histograms were produced using this same software. The $\mathrm{IC}_{50}$ were calculated from the linear or logarithmic equations of the plotted curves.

\section{Results and Discussion}

\subsection{Results}

\section{Phytochemical composition of the different extracts}

The results showed the presence of certain biologically active molecules such as flavonoids, terpenoids and tannins. Terpenes and alkaloids are also found in aqueous extracts. On the other hand, the tests were negative for saponosides, reducing compounds, glycosides and free anthracenes. Table 1 indicates the presence of the various groups sought.

\section{Extraction yields}

For the four types of extracts studied, the value of their dry extract yields based on their dry weight is shown in the following Table 2 .

\section{Determination of polyphenols}

It determined the amount of all phenolic compounds contained in each type of extract. A calibration curve is therefore drawn from the gallic acid taken as a reference (Figure 1). Thus, the polyphenol content is calculated from this curve and expressed in $\mathrm{mg}$ of gallic acid equivalent per gram of dry extract (mg GAE/g DE) (Figure 2).

Measurement of the activity of 2,2-diphenylpicrylhydrasil DPPH

By studying the anti-radical activity of the extracts, it was possible to 
Table 1. Result of the phytochemical screening of Chenopodium ambrosioides.

\begin{tabular}{ccccc}
\hline \multirow{2}{*}{ Groupes chimiques } & \multicolumn{2}{c}{ Macération } & \multicolumn{2}{c}{ Infusion } \\
\cline { 2 - 5 } Flavonoïdes & Eau distillée & Ethanol & Eau distillée & Ethanol \\
Tanins & + & + & + & + \\
Alcaloïdes & + & + & + & + \\
Saponosides & + & - & + & - \\
Terpénoïdes & - & - & - & - \\
Terpènes & + & + & + & + \\
Composés réducteurs & + & + & + & + \\
Glycosides cardiaques & - & - & - & - \\
Anthracéniques libres & - & - & - & - \\
Quinines & - & - & - & - \\
\end{tabular}

$(+)=$ positive reaction, $(-)=$ negative reaction.

Table 2. Result of the extraction yields.

\begin{tabular}{|c|c|c|}
\hline \multicolumn{2}{|c|}{ Types of extracts } & \multirow{2}{*}{$\begin{array}{l}\text { Yields } \\
17.48 \%\end{array}$} \\
\hline & Water & \\
\hline \multicolumn{3}{|l|}{ Maceration } \\
\hline & Ethanol & $5.85 \%$ \\
\hline & Water & $15.63 \%$ \\
\hline \multicolumn{3}{|l|}{ Infusion } \\
\hline & Ethanol & $5.27 \%$ \\
\hline
\end{tabular}

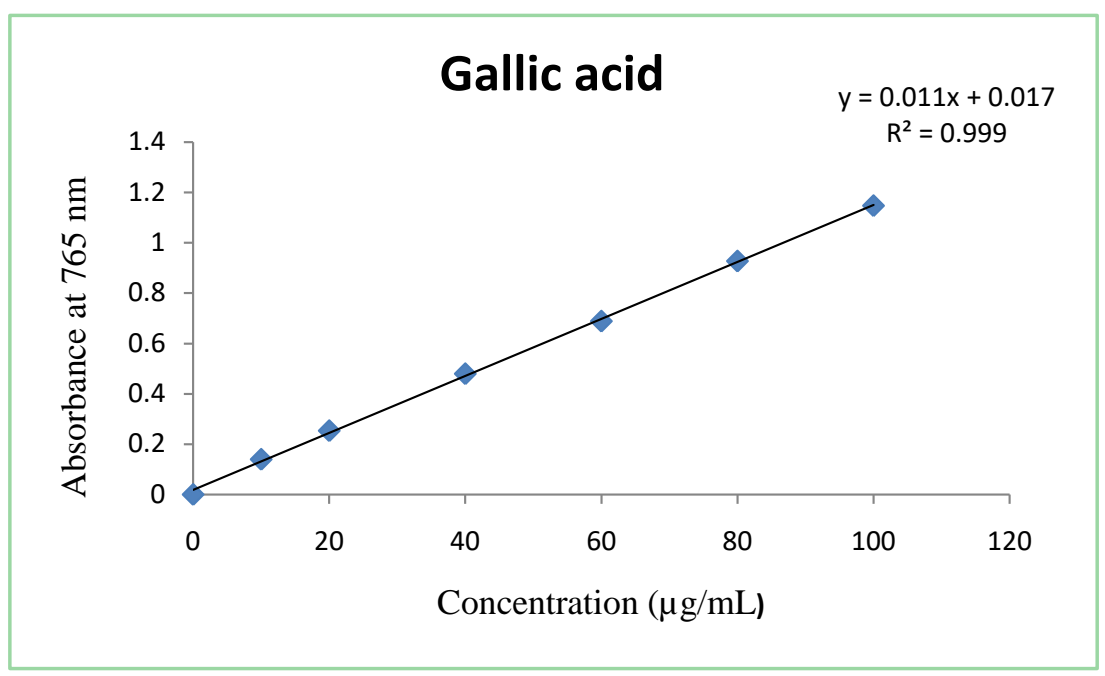

Figure 1. Gallic acid calibration curves. 


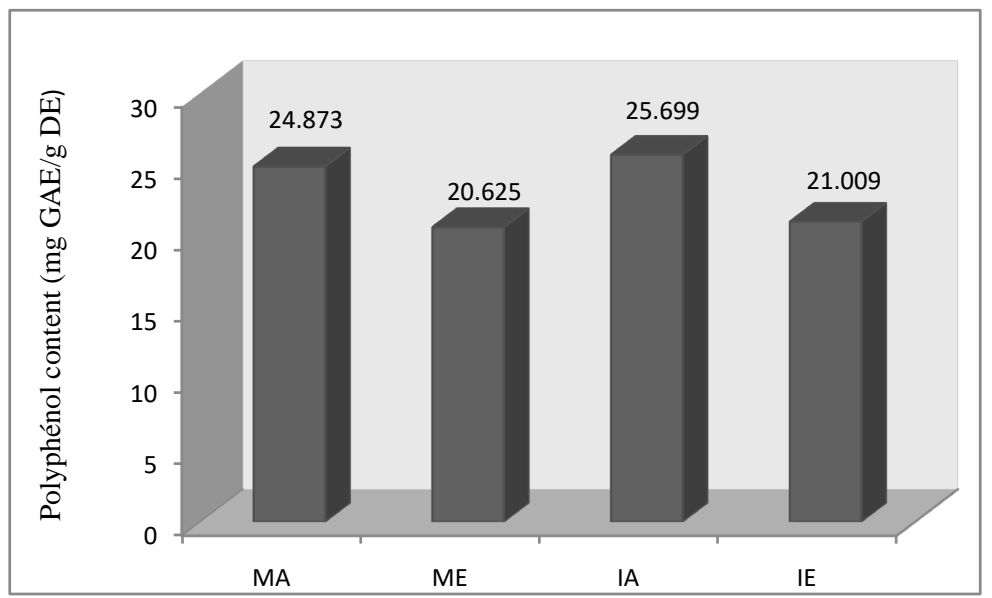

Figure 2. Comparison of the polyphenol contents of Chenopodium ambrosioides extracts.

determine which extract showed the most activity. The absorbance of the ethanolic solution of DPPH read at $517 \mathrm{~nm}$ is 0.908 . From the different values of the absorbances obtained and the corresponding concentrations, a curve was drawn. This determined the concentration that degraded half of the initial absorbance of DPPH $\left(\mathrm{IC}_{50}\right)$ (Figures 3-7).

\section{Determination of $\mathrm{IC}_{50}$}

It is used to estimate the reducing activity. $\mathrm{An} \mathrm{IC}_{50}$ value expresses the concentration capable of trapping $50 \%$ of the $\mathrm{DPPH}$ radical and therefore a low $\mathrm{IC}_{50}$ represents the highest anti-radical activity. The values of the $\mathrm{IC}_{50}$ concentrations are reported in the following Table 3.

\subsection{Discussion}

Recent studies carried out in Benin by Koumodji [16] and Houngnimassoun et al. [17] have shown the presence of alkaloids, catechic tannins, flavonoids, saponosides. In our phytochemical screening, saponosides were absent; but like the studies in Benin, there is an absence of reducing compounds. According to the work of Ehiabhi [10] from Nigeria the phytochemical screening of the same plant reveals the presence of alkaloids, tannins, flavonoids, terpenes and sugars. This is in line with our work except in our tests the sugars were absent.

Rubabura et al. [18] from DR Congo for their part identified in aqueous and ethanolic extracts alkaloids, tannins, steroids, glycosides, terpenes and phenols. Finally, Valério et al. [7] also did the phytochemical screening of the plant in Brazil, but the results have not been published.

\section{Effectiveness of the nature of the solvent compared to the method}

According to Table 2, the yields obtained by maceration are higher than those of infusion regardless of the solvent used. In addition, the aqueous extracts have a higher yield than the ethanolic extracts. The difference in yields between these extracts is believed to be due to a number of factors such as: the extraction method used and the nature of the solvent. These results show that there is a dif- 
ference between the extraction technique used on the one hand and the nature of the solvent on the other hand.

Table 3. IC $\mathrm{C}_{50}$ value for the DPPH test.

\begin{tabular}{ccc}
\hline Type of extract & Curve equation & $\mathrm{IC}_{50}(\mu \mathrm{g} / \mathrm{mL})$ \\
\hline Quercetin & $\mathrm{Y}=-0.0276 \mathrm{X}+0.7681$ & 11.380 \\
Aqueous infusion & $\mathrm{Y}=-16.256 \mathrm{X}+0.8692$ & 25.541 \\
Ethanolic infusion & $\mathrm{Y}=-8.6536 \mathrm{X}+0.8717$ & 269.187 \\
Aqueous maceration & $\mathrm{Y}=-13.451 \mathrm{X}+0.8466$ & 50.999 \\
\hline
\end{tabular}

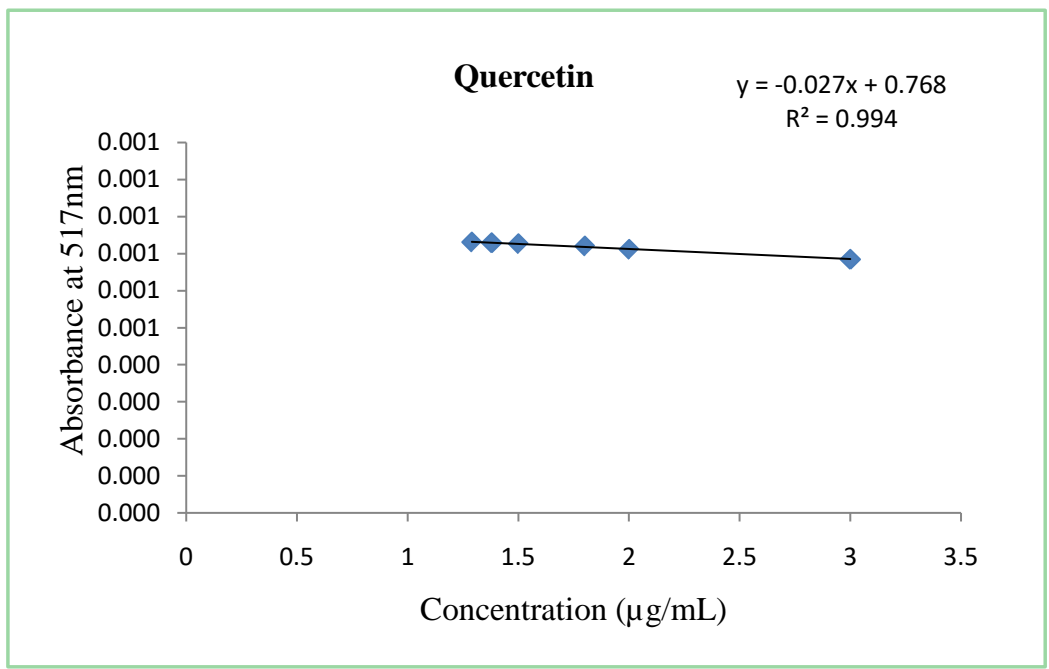

Figure 3. Change in absorbance as a function of the concentration of quercetin.

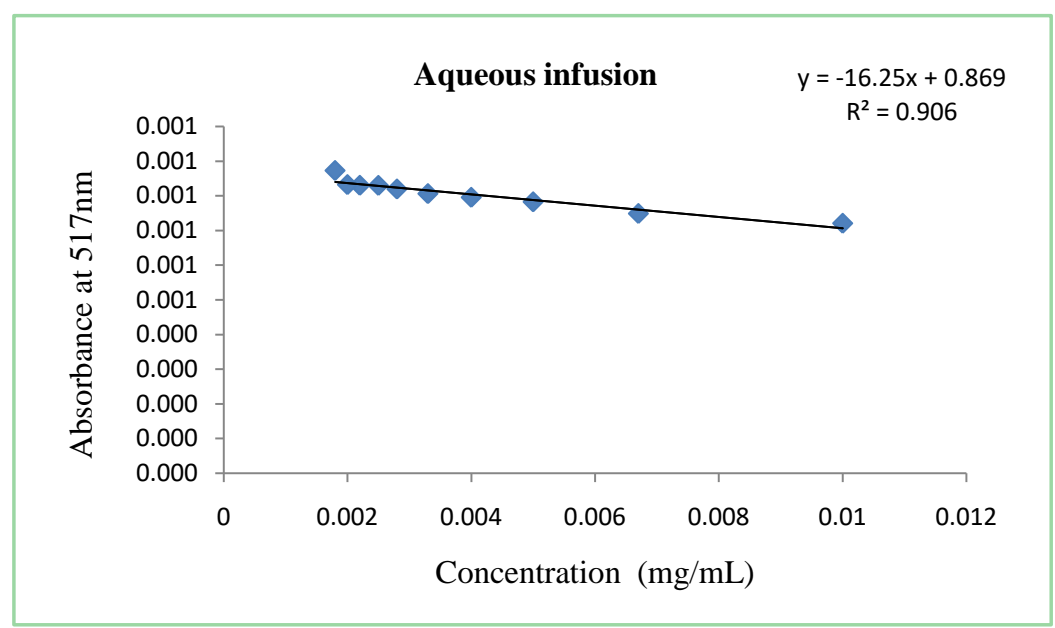

Figure 4. Change in absorbance as a function of the concentration of the aqueous infusion of Chenopodium ambrosioides. 


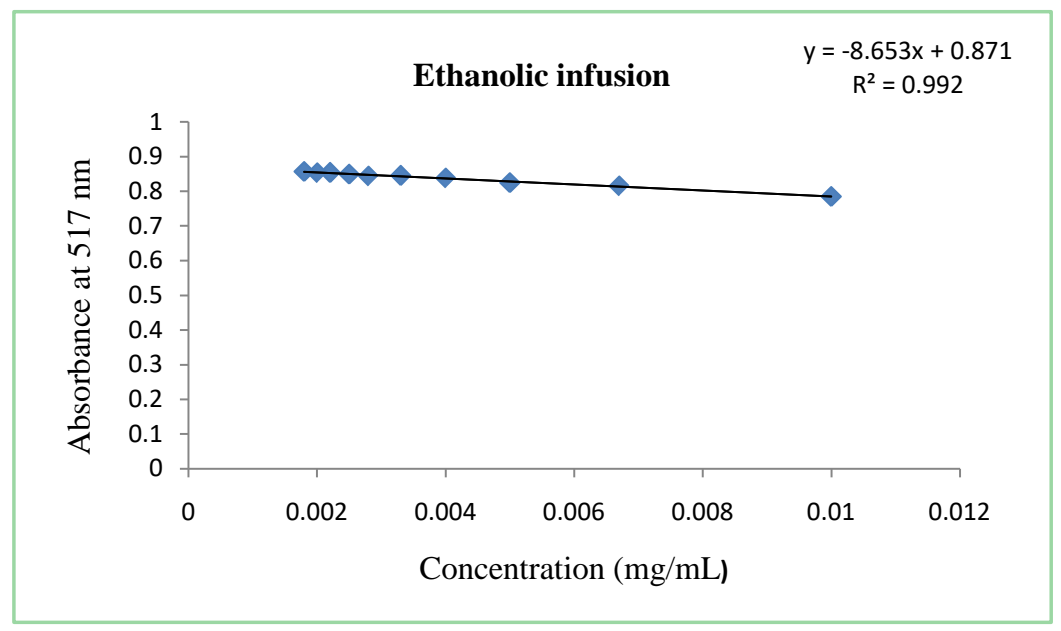

Figure 5. Change in absorbance as a function of the concentration of the ethanolic infusion extract of Chenopodium ambrosioides.

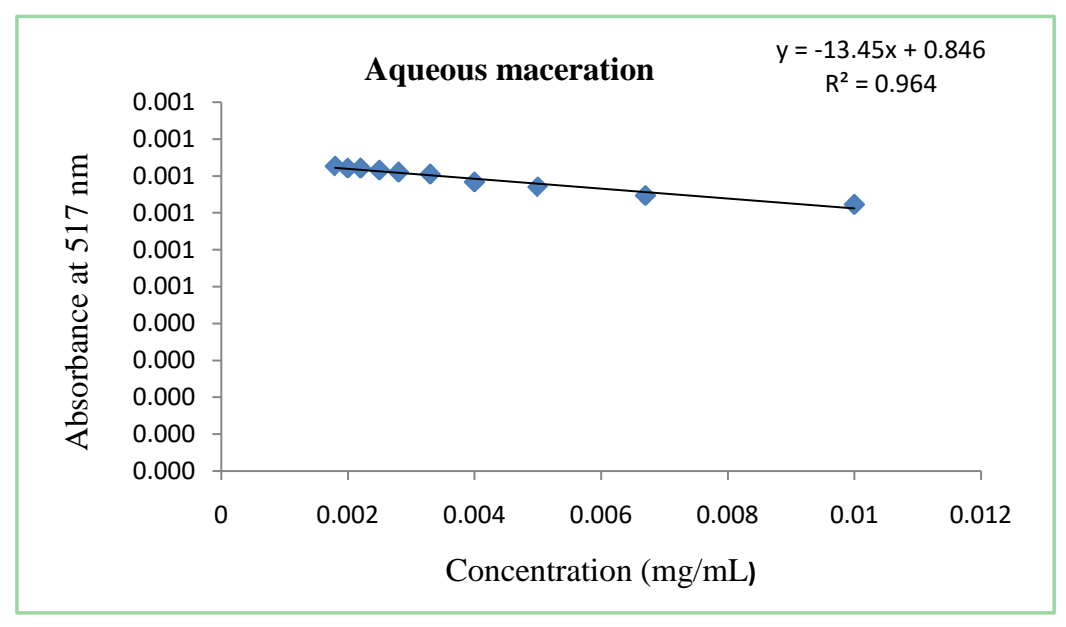

Figure 6. Change in absorbance as a function of the concentration of the aqueous maceration of Cheneopodium ambrosioides.

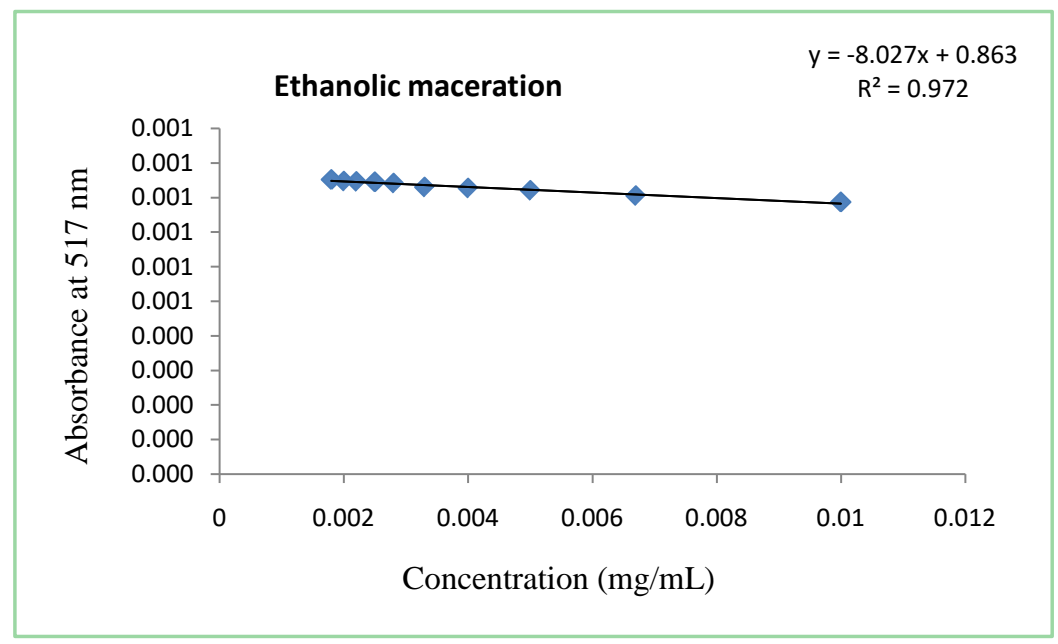

Figure 7. Change in absorbance as a function of the concentration of ethanolic maceration of Chenopodium ambrosioides. 
The study carried out by Houngnimassoun et al. [17] where the yield of aqueous extraction by the maceration technique is estimated at $13.77 \%$ shows a slight difference with our results. This may be due to environmental factors taking into account the geographical conditions.

These results are not far from the phytochemical screening carried out where distilled water further identified secondary metabolites.

The results of the assay show that there is a small difference between the contents of polyphenols. Indeed, the aqueous extracts have a high content with $25.699 \mathrm{mg}$ AGE/g DE and $24.873 \mathrm{mg} \mathrm{AGE/g} \mathrm{DE} \mathrm{respectively} \mathrm{for} \mathrm{the} \mathrm{aqueous} \mathrm{infused} \mathrm{and}$ the aqueous macerate, against $21.009 \mathrm{mg} \mathrm{AGE} / \mathrm{g} \mathrm{DE}$ for the ethanolic infusion and $20.625 \mathrm{mg}$. AGE/g DE for the ethanolic macerate. These values show that the amount of polyphenols varies from one solvent to another and from one technique to another.

A study by Amine et al. [19] on three aqueous extracts showed that the decocted has a high polyphenol content followed by the infused and after the macerate; which confirms our results. Also, Villalobos-Delgado et al. [20] showed in their study that the infusion of Chenopodium ambrosioides contained a high concentration of phenolic compound compared to the ethanolic extract obtained by maceration.

Considering a solvent, these results demonstrate that the infusion allows a good extraction of the phenolic compounds for this species.

\section{About the anti-radical study of the extracts}

The reduction potential of the DPPH radical is determined by a decrease in the absorbance caused by anti-radical compounds. The results giving the $\mathrm{IC}_{50}$ values show the ability of the different extracts to reduce the DPPH radical at different concentrations. These values are $11.380 \mu \mathrm{g} / \mathrm{mL}$ for the reference (quercetin), 25.541 $\mu \mathrm{g} / \mathrm{mL}$ for the Aqueous Infusion (AI); $29.187 \mu \mathrm{g} / \mathrm{mL}$ for Aqueous Maceration (AM) followed by Ethanolic Infusion (EI) with $48.269 \mu \mathrm{g} / \mathrm{mL}$ then Ethanolic Maceration (EM) with $50.999 \mu \mathrm{g} / \mathrm{mL}$. This shows that the aqueous extract by infusion reacted more with the DPPH followed by the aqueous extract by mace- ration after the ethanolic infusion and the ethanolic macerate where the order of reduction is as follows: $\mathrm{QEC}>\mathrm{AI}>\mathrm{AM}>\mathrm{EI}>\mathrm{EM}$. This order of reduction could be due to the content of each extract in metabolites. It could also be that the macerates contain a combination of secondary metabolites, which could be the cause of their low reactivity vis-à-vis the DPPH radical. These results show that distilled water is predominant over ethanol and that infusion is the best technique for extracting anti-radical compounds for this plant species. These differences between the $\mathrm{IC}_{50}$ values of the different extracts are linked to the nature of the solvent and the extraction method.

The results of some researchers such as Barros et al. [1] revealed that the aqueous infusion of Chenopodium ambrosioides exhibits greater anti-radical activity compared to that of the methanolic extract. In addition, Zbadi et al. [21] in their study showed that the aqueous extract of the plant has a great anti-radical power 
compared to the ethanolic extract. This work therefore confirms our results.

\section{Conclusion}

At the end of this study, the yields and the different phytochemical groups present in each extract of Chenopodium ambrosioides were determined. The results show that distilled water is the best solvent in terms of yields and maceration is the best extraction technique under our experimental conditions. With the exception of saponosides, reducing compounds, cardiac glycosides and free anthracenes which tested negative in all extracts, the phytochemical test showed the presence of flavonoids, tannins, terpenoids and terpenes. Alkaloids are only present in aqueous extracts. The aqueous extracts are more anti-radical than the ethanolic extracts. However, it is the extracts by infusion which lead to better anti-radical activity. The solvent and the technique used greatly influenced the results obtained. Therefore, a more in-depth study would make it possible to improve the yield by other techniques, to target the compound(s) responsible for the activity of each extract and then to identify any heavy metals present in the different aerial parts of Chenopodium ambrosioides.

\section{Conflicts of Interest}

The authors declare no conflicts of interest regarding the publication of this paper.

\section{References}

[1] Barros, L., Pereira, E., Calhelha, R.C., Duenas, M., Carvalho, A.M., Santos-Buelga, C. and Ferreira, I.C.F.R. (2013) Bioactivity and Chemical Characterization in Hydrophilic and Lipophilic Compounds of Chenopodium ambrosioides L. Journal of Functional Foods, 5, 1732-1740. https://doi.org/10.1016/j.jff.2013.07.019

[2] Djassinra, T., Kribii, A. and Ounine, K. (2015) Evaluation de l'effet protecteur des extraits aqueux de Chenopodium ambrosioides L et de Rosmarinus officinalis L vis-à-vis des plantes de tomate inoculées par la souche Xanthomonas fragariae Dw. International Journal of Innovation and Scientific Research, 15, 30-38. http://www.ijisr.issr-journals.org/

[3] N’guessan, K., Kadja, B., Zirihi, G., Traoré, D. and Aké-Assi, L. (2009) Screening phytochimique de quelques plantes médicinales ivoiriennes utilisées en pays Krobou (Agboville, Côte-d'Ivoire). Sciences \& Nature, 6, 1-15. https://doi.org/10.4314/scinat.v6i1.48575

[4] Tettegah, M., Eklu-Kadegbeku, K., Aklikokou, A.K., Agbonon, A., De Souza, C. and Gbeassor, M. (2009) Infected Wound Healing and Antimicrobial Effects of Chenopodium ambrosioides and Mitracarpus scaber. International Journal of Biological and Chemical Sciences, 3, 623-627. https://doi.org/10.4314/ijbcs.v3i3.45329

[5] Dieng, S.I.M., Fall, A.D., Diatta-Badji, K., Sarr, A., Sene, M., Sene, M., Mbaye, A., Diatta, W. and Bassene, E. (2017) Evaluation de l'activité antioxydante des extraits hydro-ethanoliques des feuilles et écorces de Piliostigma thonningii Schumach. International Journal of Biological and Chemical Sciences, 11, 768-776. https://doi.org/10.4314/ijbcs.v11i2.19

[6] Mostafa, E.I., Mohammed, E., Ali, A., Adrae, L., Saadia, B. and Ghizlane, E. (2016) Caractérisation chimique des huiles essentielles de Chenopodium ambrosiö̈des (L.) 
(Chenopodiaceae) de quatre regions du Maroc [Chemical Characterization of Essential Oils from Chenopodium ambrosioides (L.) (Chenopodiaceae) from Four Regions of Morocco]. Journal of Materials and Environmental Science, 7, 4087-4095.

http://www.jmaterenvironsci.com/

[7] Valério, E.S., Barbosa, W.L.R., Finger, R.M., Muzitano, M.F., Araújo, M.H., Vasconcelos, F. and Teixeira, F.M. (2015) Physicochemical Characterization, Microbiological Quality Control and Toxicity Evaluation of the Hidroethanolic Extract from Chenopodium ambrosioides Linn. International Journal of Pharmaceutical Sciences and Research, 6, 4190-4197.

[8] Kiyuchi, F., Itano, Y., Uchiyama, N., Honda, G., Tsubouchi, A., Nakajima-Shimada, J. and Aoki, T. (2002) Monoterpene Hydroperoxides with Trypanocidal Activity from Chenopodium ambrosioides. Journal of Natural Products, 65, 509-512. https://doi.org/10.1021/np010445g

[9] Pollack, Y., Segal, R. and Golenser, J. (1990) The Effect of Ascaridole on the in Vitro Development of Plasmodium falciparum. Parasitology Research, 76, 570-572. https://doi.org/10.1007/BF00932563

[10] Okhale, S.E., Omoregie, H., Comfort, O.E., Folashade, O., et al. (2012) Phytochemical and Proximate Analyses and Thin Layer Chromatography Fingerprinting of the Aerial Part of Chenopodium ambrosioides Linn. (Chenopodiaceae). Journal of Medicinal Plants Research, 6, 2289-2294.

[11] Tapondjou, L.A., Adler, C., Boud, H. and Fontem, D.A. (2002) Efficacy of Powder and Essential Oil from Chenopodium ambrosoides Leaves as Post-Harvest Grain Protectants against Six-Stored Product Beetles. Journal of Stored Products Research, 38, 395-402. https://doi.org/10.1016/S0022-474X(01)00044-3

[12] Haddouchi, F., Chaouche, T.M. and Halla, N. (2016) Screening phytochimique, activités antioxydantes et pouvoir hémolytique de quatre plantes sahariennes d'Algérie. Phytothérapie. https://doi.org/10.1007/s10298-016-1086-8

[13] EL-Haoud, H., Boufellous, M. and Berrani, A. (2018) Screening phytochimique d'une plante medicinale: Mentha spicata L. American Journal of Innovative Research and Applied Sciences, 226-233.

[14] Halla, N., Boucherit, K., Boucherit-Otmani, Z., Touati, F.Z., Rahmani, N. and Aid, I. (2019) Ammodaucus leucotrichus and Citrullus colocynthis from Algerian Sahara: Ethnopharmacological Application, Phytochemical Screening, Polyphenols Content and Antioxidant Activity of Hydromethanolic Extracts. Journal of King Saud University-Sciences, 31, 541-548. https://doi.org/10.1016/j.jksus.2018.03.018

[15] Ali-Rachedi, F., Meraghni, S., Halla, N. and Mesbah, S. (2018) Analyse quantitative des composés phénoliques d'une endémique algérienne Scabiosa Atropurpurea sub. Maritima L. Bulletin de la Société Royale des Sciences de Liège, 87, 13-21.

[16] Koumodji, K.D. (2016) Etude préliminaire de la prévalence de Blattella germanica dans la commune d'Abomey-Calavi et de sa sensibilité à des extraits de Chenopodium ambrosiö̈des (L), Université d'Abomey-Calavi, Benin.

[17] Houngnimassoun, H.M.A., Salifou, S. and Houetan, G.D. (2020) Enquête parasitologique et effet nématodicide in vitro des extraits aqueux des feuilles de Spondias mombin L. 1753 (Anacardiaceae) et de Chenopodium ambrosioides L. 1753 (Chenopodiaceae) sur Ascaridia galli, nématode de l'intestin grêle du poulet. Journal of Animal \& Plant Sciences, 43, 7380-7392.

[18] Rubabura, J.A.K., Bagalwa, J.J.M., Lorena, A.C., Masunga, C.L. and Mugisho, J.B.L. (2020) Biocidal Activities of Chenopodium ambrosioides and Tagetes minuta against Antestiopsis orbitalis ghesquierei carayon (Heteroptera: Pentatomoidae) In Vitro. 
International Journal of Pharmacognosy and Phytochemical Research, 12, 60-65.

[19] Amine, D., Mohamed, B., Zoubida, H., Jamal, I. and Laila, N. (2017) Activite antifongique des extraits aqueux de Calendula Officinalis L, Urginea Maritima (L.) Baker et Chenopodium Ambrosioides L. European Scientific Journal, 13, 483-497. https://doi.org/10.19044/esj

[20] Villalobos-Delgado, L.H., González-Mondragón, E.G., Govea, A.Y.S., Andrade, J.R. and Santiago-Castro, J.T. (2017) Potential Application of Epazote (Chenopodium ambrosioides L.) as Natural Antioxidant in Raw Ground Pork. LWT-Food Science and Technology, 84, 306-313. https://doi.org/10.1016/j.lwt.2017.05.076

[21] Zbadi, R., Mohti, H. and Moussaoui, F. (2018) Stress Oxydatif: Evaluation du pouvoir antioxydant de quelques plantes médicinales. Médecine Translationnelle, 24, 134-141. 